\title{
EXPERT STUDIES OF VIOLATIONS OF THE OPERATING CONDITIONS OF AUTOMOBILE ENGINES WHEN USING THEM IN AVIATION
}

\author{
Khrulev A. E. ${ }^{1}$, Sarayeva I. Y.1 \\ ${ }^{1}$ Kharkiv National Automobile and Highway University
}

\begin{abstract}
Problem. The features of the design and operation of piston engines in general aviation are considered. Comparative analysis of design features and parameters of automobile and aircraft engines is carried out. It is shown that car engines, despite the high technical level achieved at the beginning of the 21st century, do not technically meet aviation requirements. At the same time, engines created on the basis of automobiles through their deep modernization meet aviation requirements, however, modernization and adaptation of a standard automobile engine to aviation use in terms of costs compared to the creation of a new engine. Purpose. Carry out research on the failure of automobile engines used in light aviation. Methodology. Rough calculations of the service life of an automobile engine were made based on standard driving tests and a flight plan. According to the results of calculations, it has been established that the resource of a standard automobile engine in aviation is reduced many times due to prolonged operation at high loads and rotational speed that are not characteristic of ordinary automotive applications. Results. Experimental data have been obtained on the actual failure of standard automobile engines in aviation during the operating time, significantly less resource of aircraft engines of well-known brands. Based on the results of the study, it was concluded that the use of general aviation automobile engines is economically ineffective due to a short resource and insufficient reliability. Originality. Modern automobile engines, despite their technical perfection, cannot be used in aviation, since they do not correspond to aviation operating conditions. At the same time, adaptation of automobile engines to aviation applications is possible, but requires significant design changes, which makes their single use, as a rule, technically impractical and economically ineffective. Practical value. Due to the fact that saving on an aircraft engine is unacceptable from the point of view of flight safety, the aviation use of automobile engines without special modernization carries excessive risks of failures and their consequences. As a result, serial aircraft engines Lycoming, Continental, Jabiru, ULPower, Rotax, Limbach and others have virtually no alternative in general aviation.
\end{abstract}

Keywords. transport, engine, diagnostics, malfunction, failure, driving cycle, expertise.

\section{Introduction}

The task of equipping newly constructed aircrafts with an engine has been relevant, since the very first designs appeared [1]. It is usually solved in two ways - by creating a new engine, adhering to specific technical requirements for aircraft, or by selecting a suitable engine from existing ones $[2,3]$. However, in general aviation the relatively low cost of an aircraft in some cases conflicts with the high price of serial aircraft piston engines and spare parts for them, causing technical and organizational difficulties in servicing them. This situation explains the ongoing attempts by some aircraft developers to find a cheaper alternative to mass-produced aircraft engines [4].

\section{Analysis of publications}

It is known that the design of aircraft piston internal combustion engines received its very rapid development in aviation during the 2nd World
War. In that time the specific power of aircraft piston engines more than doubled, because it was a main condition for their effective aviation application [5].

As a result, by 1945 an extremely high and practically modern level of specific power of 70 hp / liter was achieved in aviation (British Napier engines). A typical aircraft piston engine has received its characteristic and preserved appearance to this day (Figure 1), including [1, 2, 7] lightweight aluminum or magnesium housing parts, a large number of cylinders (limitation of absolute sizes to suppress detonation at high specific power) and a low rotation speed (the need to coordinate the engine with a propeller, limit mass and increase the reliability of the gearbox).

In addition, it should be noted as a whole the extremely loaded construction of the parts in combination with expensive high-quality mate- 
rials (in order to ensure a long durability at high specific power).

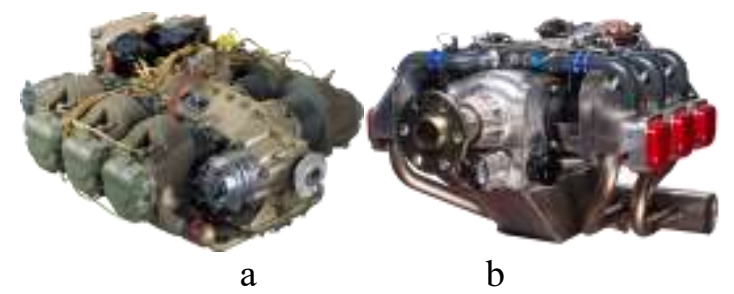

Fig. 1. Typical modern aircraft piston engines: a - design of the 30-40s of the 20th century (Continental); $b$ - design of the beginning of the 21 st century (ULPower).

\section{Purpose and problem statement}

The aim of the work is to conduct research on the failures of automobile engines used in light aviation.

The main tasks of the work:

- determine the range and main technical characteristics of automobile engines that are used in small aircraft;

- estimate the service life of an automobile engine when operating as part of an aircraft power plant.

\section{Comparison of internal combustion engines for aviation and automotive applications}

Currently there are several major manufacturers of piston engines for general aviation in the power range of 50-400 hp (Table 1).

Table 1 - The main parameters of the most popular aircraft piston engines

\begin{tabular}{|l|c|c|c|c|c|c|}
\hline \multicolumn{1}{|c|}{ Manufacture } & Lycoming & Continental & Rotax & Jabiru & ULPower & Limbach \\
\hline Power, hp & $110-400$ & $50-230$ & $65-141$ & $80-120$ & $100-200$ & $60-160$ \\
\hline Rpm & $2500-2800$ & $2000-2700$ & 5800 & 3300 & 3300 & $3000-3600$ \\
\hline Year of design & 1930 & 1930 & 1975 & 1995 & 2006 & 1970 \\
\hline
\end{tabular}

All the aircraft engines in this class are boxer, 4-6-8-cylinder type, with lower camshaft $(\mathrm{OHV})$ and cam follower rods; most of them are air-cooled with electronic fuel injection, and the most powerful are turbocharged.

The development of the automotive engines was different from aviation and rather slow. Typical features of automotive ICEs were [8] low specific power (20-30 hp/liter), heavy cast iron housing parts, lack of boost, carburetor fuel systems, as well as the use of design solutions that were not the best in terms of reliability, which is generally explained as the desire to minimize cost. As a result, the average automotive ICE of the 40-80s of the last century was generally unsuitable (with the exception of single models) for aviation applications, due to the complete discrepancy in specific parameters, not only because of the low specific power, but also due to the high specific gravity. Moreover, for more than half a century since the end of intensive research on the creation of new designs of piston ICEs for manned aircraft in the late 40s of the last century and until about 2000, the old aircraft engine designs were ahead of automotive ones. All this actually made attempts to use automotive ICEs in aviation ineffective or even technically unacceptable [9].
However, by the end of the 20th century two accelerating factors had worked toward the development of automotive ICEs - the fuel and energy crisis (a gradual but significant increase in hydrocarbon fuel prices) and a serious tightening of environmental requirements. As a result, with a delay of about 50-60 years, automotive ICE caught up with and surpassed the old aircraft engine designs in most respects. So, the specific power of automotive engines has long exceeded $70 \mathrm{hp} /$ liter, turbo- and supercharging has become extremely widespread, and light alloys for housing parts have finally replaced cast iron (even on relatively heavy diesels). In addition, the cheap elements that could reduce reliability have gradually disappeared from the designs $[8,10]$. That is why with a delay of about half a century the automotive ICEs have acquired many features of aircraft piston engines (Figure 2), but at the same time very large series made the cost of automotive ICEs significantly lower than the cost of aircraft engines.

It is known that the most popular aircraft piston engines of the 40 s for 75-80 years of production and operation have a long-established level of reliability, but are quite expensive. At the same time, the creation of new aircraft engines is problematic, since it is extremely costly. In such conditions, the question again arises of the 
use of automotive ICEs in general aviation as a possible alternative and a way to save. It should be noted that despite the numerous attempts to apply automotive internal combustion engines in aviation, currently no uniform adaptation methods have been created and no universal recommendations have been developed for its implementation.

In accordance with this, the objective of the work is to obtain the data on the way the differences in operating conditions and modes as well as critical units and systems can affect the reliability of an automotive engine adapted to its application in aviation, as well as to analyze the features and prospects of the use of automotive ICEs in aviation.

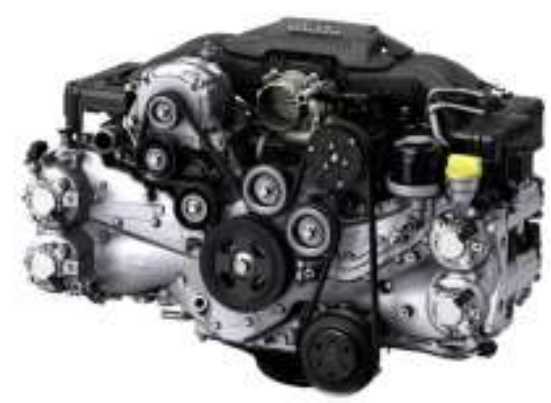

a

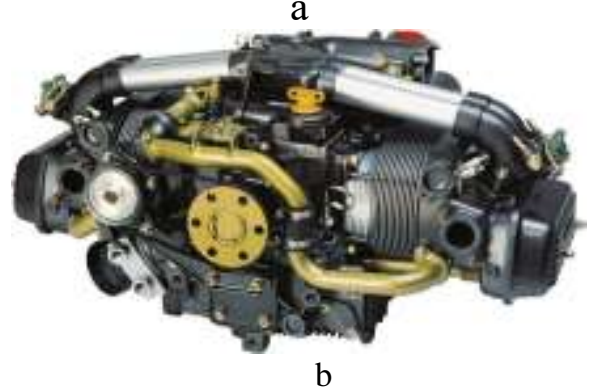

Fig. 2. Engines: a - Subaru car engine has examples of aviation applications; $b$ - Limbach aircraft engine, created by the deep modernization of the old automotive boxer engine VW

Failure statistics for aircraft piston engines shows that about half of all failures occur in the mechanical part [11, 12]. In accordance with this, the design of the engine itself determines the possibilities of its application [13]. To identify differences in the design that may limit the engine application, it is necessary, first of all, to consider the basic requirements for piston engines for aviation. Such requirements can be formulated as the main typical design solutions that ensure the reliability of aircraft ICEs, including:

- drive of the valve mechanism - it requires high reliability, which is provided only by the gears. The belt and chain drives widely used in automotive industry do not satisfy this requirement;

- piston materials - must localize damage and exclude complete engine failure due to damage in individual cylinders, which is achieved using special plastic piston materials. Well-known automotive piston alloys based on silumin do not meet such requirements;

- lubrication system - should solve the problem of uninterrupted oil supply to friction pairs under conditions of aircraft evolution. In aviation such requirements are met by a lubrication system with an oil tank and a dry sump, which is practically not found in mass-produced automotive engines;

- engine control system - in modern aviation it is an electronic system with high noise immunity and duplication of the functions (including with two spark plugs operating in parallel, and in some cases, fuel nozzles). Serial automotive designs, as a rule, do not meet these requirements.

As a result of all these inconsistencies, any attempt to use an automotive engine in aviation encounters design problems caused by the fundamental structural differences between automotive and aircraft ICEs. Moreover, the changes in the design of automotive ICE are technically difficult or even impossible, due to the fact that any such engine was originally created for other requirements.

This means that bringing such ICE to aviation requirements is practically equivalent to creating an aircraft engine again. And this entails new problems, namely, that a single engine of a unique design and its production are extremely expensive, a series is required for payback, but there is no necessary demand for it, because of the inability to compete in the market with traditional manufacturers [14]. In such conditions the creation of a new aircraft engine becomes almost impossible for economic reasons.

Nevertheless, the examples of applications of the automotive engines in aviation are currently known. These are the engines, including those made by VW, Porsche, Subaru, Honda and some other companies used mainly as prototypes. Such engines could be divided into 2 groups aircraft ICEs, specially developed on the basis of automotive ones, and automotive ICEs, adapted in one way or another to application in aviation. Most of them are made according to the boxer scheme [15].

The first group should include Limbach serial aircraft engines, created on the basis of the 
old automotive boxer 4-cylinder VW engine through its deep modernization (Figure 2). The Porsche 6-cylinder aircraft engine was made similarly (Figure 3 ). It is characteristic that the design of these ICEs, unlike the basic prototypes, meets all the aviation requirements listed above (including two independent ignition and fuel supply systems). Also, it is clear that behind such developments is usually a serious manufacturer, which implies a serious approach to the problem.

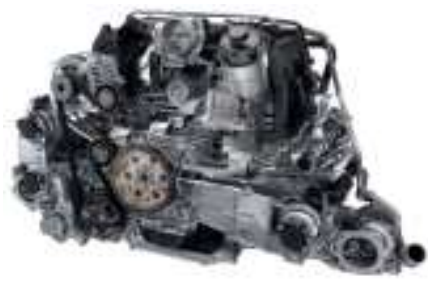

a

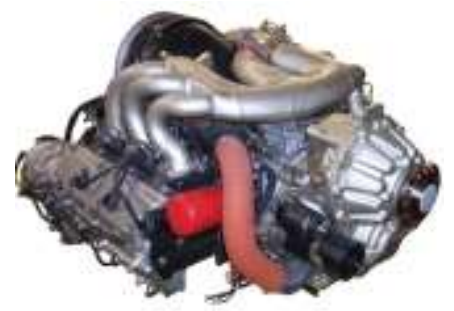

b
Unfortunately, none of this can be said about the engines of the second group. Their adaptation mainly concerns external connections and, as a rule, does not affect the internal components and parts [9].

Typically, such a simplified approach is caused by the desire of the aircraft developer to get maximum savings on engine costs. Usually this is due to a lack of his understanding of the aviation specifics [16], including the differences in the design and operating conditions of automotive and aircraft ICEs, and the wish to obtain savings at all the costs.

In fact, in this case we are talking about the inappropriate use of the engine in completely different conditions than were laid down during its design and production. From here one can already expect a significant difference in the durability of a particular automotive engine on a car and in the composition of an aircraft power plant. Moreover, this difference is completely obvious.

Indeed, in a car the engine runs on average at low speeds and with reduced loads. This can be seen at the EUDC standard driving cycles [17] used for fuel economy and emissions testing (Figure 4).

Fig. 3. Porsche air cooled 6-cylinder boxer engines: $\mathrm{a}$ - automotive; $\mathrm{b}$ - aircraft

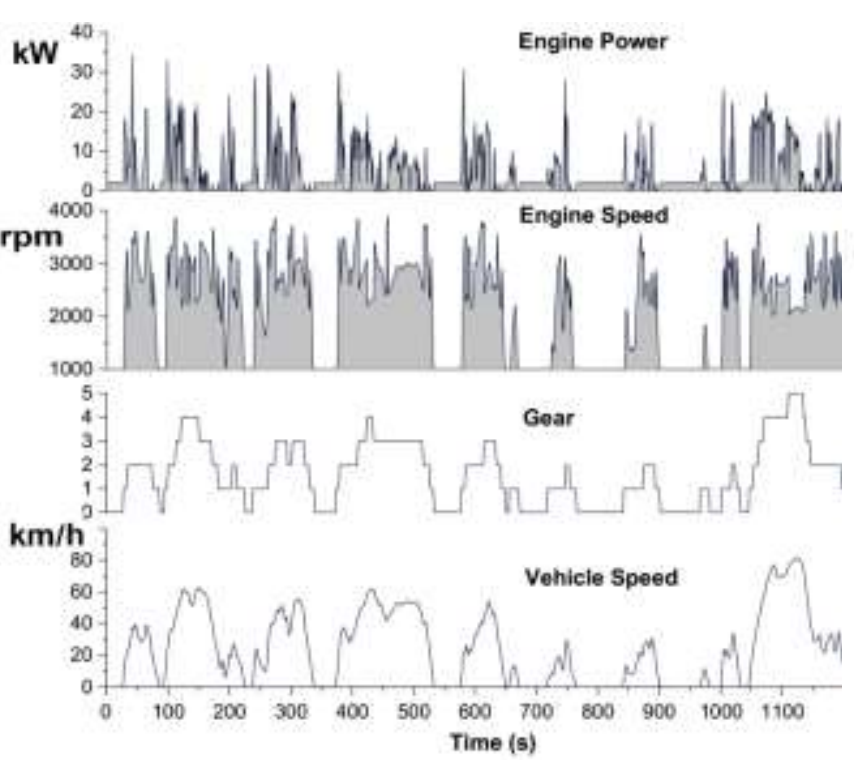

a

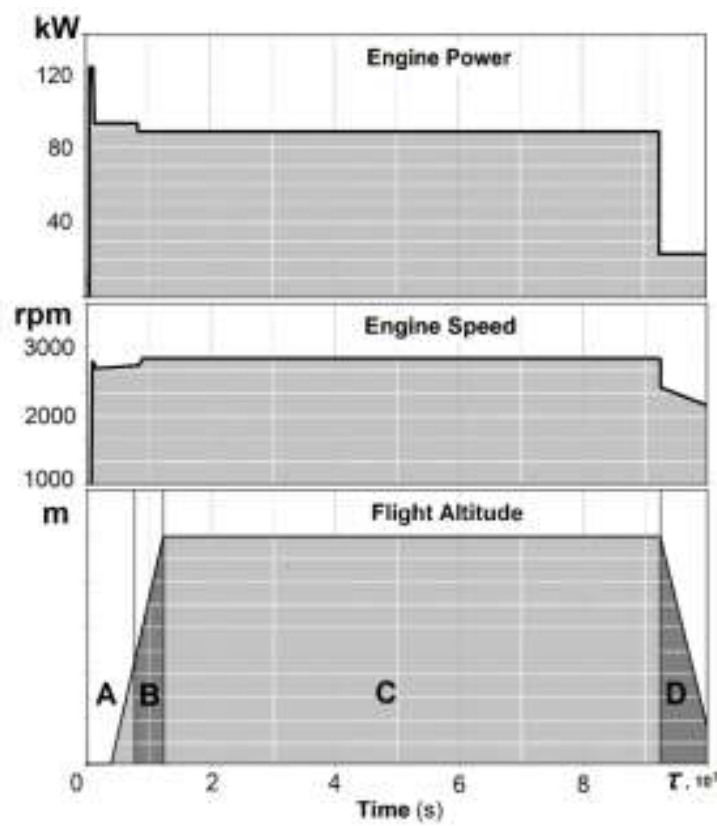

b

Fig. 4. The engine running modes by standard driving cycles (a) for automotive [17], in comparison with running modes by flight profile (b) on aircraft [18]: A - take-off, B - climb, C - cruise, D landing

The flight profile of an aircraft is significantly different from the driving cycle [18]. The main difference lies in the long-term operation at engine rated power. It follows that, in the general 
case, the same engine will have a different resource when installed on different vehicles.

Appointment of an aircraft engine resource is a rather serious and expensive task, connected, inter alia, with lengthy tests. However, with the inappropriate use of an automobile internal combustion engine in an aircraft, such tests simply have no one to conduct and nowhere to be conducted. Nevertheless, in the first approximation a calculation can be made to determine how the resource of an automobile engine will change when it is installed on an aircraft.

For an engine installed in an automobile and an aircraft, using the above driving cycles and a typical flight plan, calculation the average values of the rotation speed and load can be made by the equation:

$$
n_{m}, N_{m}=\frac{1}{\tau_{2}-\tau_{1}} \int_{\tau_{1}}^{\tau_{2}} n, N d \tau,
$$

where $n$ is rotation speed, rpm;

$M$ is the torque;

$\tau$ is the current operating time.

The usual automotive engine durability today is close to $100,000 \mathrm{~km}$ of a vehicle's mileage, provided that the resource is equal to the car warranty period. The average speed of the vehicle during testing is approximately $33 \mathrm{~km} / \mathrm{h}$ [17], which corresponds to a service life of approximately 3,000 operating hours. From tests by driving cycle, not only the vehicle speed is known, but also the engine RPM and torque. Test data processing gives the average speed of $2160 \mathrm{rpm}$ or $33 \%$ of the maximum rotation speed of $6500 \mathrm{rpm}$ and the average load per cycle $38 \%$ of the maximum.

A completely different picture is observed when considering the aircraft flight profile (Figure 4). If we calculate the average flight parameters, then the engine operating mode in terms of

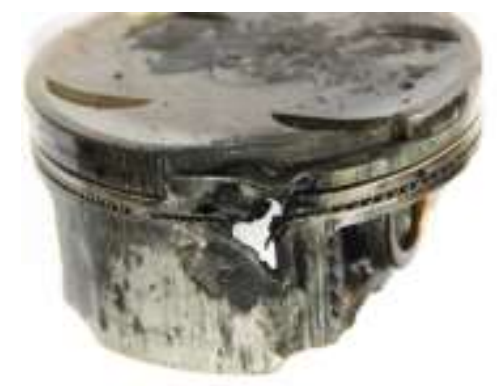

a
RPM will approach $90 \%$ of the maximum mode, and in terms of load it will be more than $62 \%$. If, for an approximate estimate, it is assumed that the durability of the internal combustion engine is inversely proportional to the load and the rotation speed, then the automobile engine as part of the aircraft power plant will get a decreased resource, approximately 4.5 times less than in a car.

However, the real difference will be even greater. Under such conditions, which are close to those specified by the flight profile (Figure 4), an automotive ICE works only in sports [19], where, due to accelerated wear at high loads and rotation speeds, the durability is no more than $10-15 \%$ of the standard and specified by the manufacturer for normal road conditions (the normal life of a sports engine rarely exceeds one racing season, during this time the mileage of sport car is only a few thousand kilometers). Then, when installed on an aircraft, the same automotive engine must have a resource (by wear) of no more than 300 hours without design changes.

It is known that most aircraft piston engines have overhaul resource (so-called TBO - Time Between Overhaul) of 5-7 times more which usually consists about 1800-2000 hours. It follows that the apparent cheapness of an automotive internal combustion engine for an aircraft application is actually not true - the use of automotive internal combustion engines in aviation without design changes is economically inefficient. Nevertheless, "cheap" solutions are always tempting, and their examples continue to appear with alarming regularity, including the giving of random unreasonable resources, due to a lack of understanding of differences in operating conditions of the engines. [20].

In Figure 5 it is shown the one such example

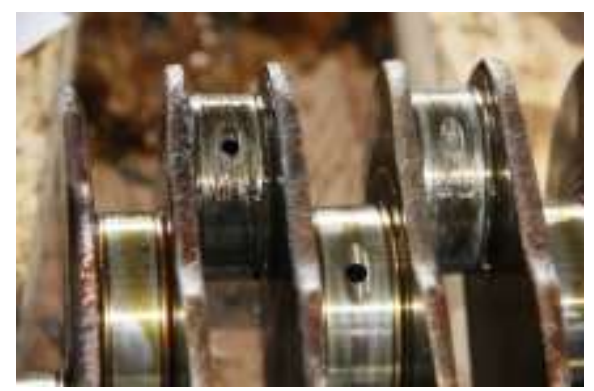

b

Fig. 5. An example of Subaru automotive engine failure during extremely long inappropriate use on an aircraft: $\mathrm{a}$ - burnout of a worn piston; $\mathrm{b}$ - destruction of worn crankshaft bearings. 
The failure of Subaru automotive ICE has occurred during an operating time of about 1000 hours on an aircraft, due to an unreasonably given resource of 2000 hours. It is characteristic that the engine not only worked up to 3 times more than its real durability up to failure, but also has confirmed this ICE did not meet aviation requirements for damage localization - it stopped in the air, due to damage in one cylinder, which led to a flight accident.

\section{Conclusions}

The modern automotive engines, despite their technical excellence, cannot be used in aviation, because they do not comply with aviation operating conditions. At the same time, the adaptation of automotive engines for aviation applications is possible, but requires significant structural changes, which makes their single use, as a rule, technically impractical and economically inefficient.

Due to the fact that saving on an aircraft engine is unacceptable from the point of view of flight safety, the aviation application of automotive engines without special modernization carries excessive risks of failures and their consequences. As a result, the produced serial aircraft engines Lycoming, Continental, Jabiru, ULPower, Rotax, Limbach and others do not actually have an alternative in general aviation.

\section{References}

1. Gunston B. World Encyclopedia of Aero Engines from the Pioneers to the Present Day 5th Edition (Sparkford: Sutton Publishing). 2006. p. 260.

2. Taylor C. F. Aircraft Propulsion. A Review of the Evolution of Aircraft Piston Engines (Washington: Smithsonian Institution Press). 1971. 134 p.

3. Taylor C. F. The internal combustion engine in theory and practice, Volume 2: Combustion, fuels, materials, design Second Edition (Cambridge: The MIT Press). 1999. 679 p.

4. Borden N. E., Cake W. J. Fundamentals of Aircraft Piston Engines Hayden Series in Aeronautical Technology (New York: Hayden Book Co.). 1971. 192 p.

5. Lumsden A. British Piston Aero Engines and their aircraft (Ramsbury: Crowood Press). 2005. 322 p.

6. Raymond R. J. Comparison of Sleeve and PoppetValve Aircraft Piston Engines (Aircraft Emgine Historical Sosiety). 2005. Vol. 5 P. 1-28. http://www. enginehistory.org/members/articles/Sleeve.pdf.

7. Gunston B. Development of Piston Aero Engines (Sparkford: Haynes Publishing). 2006. 244 p.
8. Van Basshuysen R., Schäfer F. Internal Combustion Engines. Basics, Components, Systems, and Perspectives (Warrendale: SAE International). 2004. $811 \mathrm{p}$.

9. Finch R. Converting Auto Engines for Experimental Aircraft (Osceola: Motorbooks International). 1999. $160 \mathrm{p}$.

10. Balich G. W., Aschenbach C. R. The Gasoline 4Stroke Engine for Automobiles (Notre Dame: University of Notre Dame). 2004. 156 p.

11.Aircraft Reciprocating-Engine Failure. An Analysis of Failure in a Complex Engineered System ATSB Transport Safety Investigation Report B2007/0191 (Canberra City: Australian Transport Safety Bureau) 2008. 255 p.

12. Balicki W., Głowacki P. Causes of the powerplants failures installed on Polish civil aviation aircraft (Combustion Engines, 168 vol 1) 2017. P. 110-121. doi: 10.19206/CE-2017-117.

13. Piancastelli L 2018 Powerplant Reliability Issues and Wear Monitoring in Aircraft Piston Engines. Part II: Engine Diagnostic (Drones, 2 vol 10) p 15 doi:10.3390/drones2010010.

14. Pope S. Piston Engine Aircraft Technology. Discover the latest in Piston Engine Aircraft technology (Flying, April 6). 2012. https://www.flyingmag.com/ aircraft/pistons/piston-engine-technology/

15. Flint M., Pirault J. P. Opposed Piston Engines: Evolution, Use, and Future Applications (Warrendale: SAE International). 2009, $576 \mathrm{p}$.

16. Rodriguez C. L. Piston Engines. Aviation Maintenance Technician Cert. Series (Colorado: Aircraft Technical Book Co.). 2015. 350 p.

17. Giakoumis E G 2017 Driving and Engine Cycles (Cham Springer International Publishing AG) $408 \mathrm{p}$.

18. Baechtel J. Competition Engine Building (Forest Lake: CarTech, Inc.), 2012. 178 p.

19. Frosina E., Senatore A., Palumbo L., Pascarella C. Development of a Lumped Parameter Model for an Aeronautic Hybrid Electric Propulsion System (Aerospace 5 vol 105), 2018. 25 p. doi:10.3390/aerospace5040105

20. Khrulev A., Losavio S., Drozdovsky V. Expertise of technical conditions and causes of failures of automotive vehicles (Moscow: Publishing house ABS). 2019. 966 p.

Khrulev Alexander ${ }^{1}$, Ph.D., Senior Researcher, doctoral student, alo.engine@gmail.com, +38-096616-183, https://orcid.org/0000-0002-6841-9225.

Saraieva Iryna ${ }^{1}$, Ph.D., Associate Professor, +38 050-64-00-787, e-mail: sarayeva9@ gmail.com.

${ }^{1}$ Kharkiv National Automobile and Highway University, Yaroslava Mudrogo st., 25, Kharkiv, Ukraine, 61002. 
Експертні дослідження порушень умов експлуатації автомобільних двигунів при використанні їх в авіації

Анотація. Розглянуто особливості конструкції та експлуатаиії пориневих двигунів в авіації загального призначення. Виконано порівняльний аналіз конструктивних особливостей $i$ параметрів автомобільних $і$ авіаційних двигунів. Показано, щуо автомобільні двигуни, незважаючи на високий технічний рівень, досягнутий до початку 21-го століття, технічно не відповідають авіаційним вимогам. У той же час двигуни, створені на базі автомобільних иляхом їх глибокої модернізації відповідають авіачійним вимогам, проте модернізачія та адаптація стандартного автомобільного двигуна до авіаційного застосування за витратами порівняно зі створенням нового двигуна. Мета. Провести дослідження відмов автомобільних двигунів, які використовуються в легкій авіації. Методологія. Виконано орієнтовні розрахунки ресурсу автомобільного двигуна на базі стандартних їзових тестів $і$ плану польотів. За результатами розрахунків встановлено, що ресурс стандартного автомобільного двигуна в авіачії зменшується в багато разів внаслідок тривалої експлуатаиії на режимах високих навантажень $i$ частоти обертання, не властивих звичайному автомобільному застосування. Результати. Отримано дослідні дані про фактичні відмови стандартних автомобільних двигунів в авіації при напрацююванні, істотно меншого ресурсу авіаційних двигунів відомих марок. За результатами дослідження зроблено висновок про те, щзо застосу- вання автомобільних двигунів авіації загального призначення економічно неефективно через невисокий ресурсу і недостатню надійність. Орихінальність. Сучасні автомобільні двигуні, незважаючи на їх технічна досконалість, не можуть бути використані в авіації, оскільки не відповідають авіаційним умов експлуатації. У той же час, адаптація автомобільних двигунів до авіаційного застосування можлива, але вимагає значних змін конструкиії, щзо робить їх одиничне використання, як правило, технічно недочільним і економічно неефективним. Практична цінність. У зв'язку з тим, шзо економія на авіаційному двигуні неприйнятна з точки зору безпеки польотів, авіаційне застосування автомобільних двигунів без спецііальної модернізації несе надмірні ризики відмов та ї наслідків. Внаслідок чого випускаються серійні авіаційні двигуни Lycoming, Continental, Jabiru, ULPower, Rotax, Limbach i інші фактично не мають альтернативи в авіації загального призначення.

Ключові слова: транспорт, двигун, діагностика, несправність, відмова, їздовий циикл, експертиза.

Хрулсв Олександр Едуардович ${ }^{1}$, к.т.н., с.н.с., докторант, alo.engine@gmail.com, тел. +380961632183, ORCID http://orcid.org/0000-00026841-9225.

Сарасва Ірина Юріївна ${ }^{1}$, к.т.н., доцент, тел. +38 050-64-00-787, e-mail: sarayeva9@gmail.com.

${ }^{1}$ Харківський національний автомобільнодорожній університет, 61002, Україна, м. Харків, вул. Ярослава Мудрого, 25. 